\title{
Notice to GODORT Membership
}

\section{Vote to Amend the GODORT Bylaws}

\section{General Membership Meeting, ALA Annual Conference}

Sunday, June 25, 2017

At the GODORT General Membership meeting at the 2017 ALA Conference, the membership will be asked to vote on the following proposed additions (and amendments) to the current GODORT Bylaws. These would provide for a "Bylaws and Organization Coordinator." This new officer would supplant the current Bylaws and Organization standing Committee and perform the current functions of the Committee, as defined in the GODORT Bylaws [Article XI. Amendments] and in Chapter 13 of the GODORT Policies and Procedures Manual. The underlined text will be added to Article IV (Officers), Section 1 and Section 8 [The current Section 8, which defines the GODORT Special Officers, will be re-numbered Section 9] and to Article VII (Executive Committee). Article IX (Policies and Procedures) and Article XI (Amendments), Sections 2 and 3 will need to be harmonized, to reflect substitution in the Bylaws of "Bylaws and Organization Coordinator" for references to the Bylaws Committee and Chair of the Bylaws Committee:

\section{Article IV. OFFICERS}

Section 1.

Officers of the Round Table are elected and shall be Chair, Assistant Chair/ Chair-Elect, Immediate Past Chair, Secretary, Treasurer, GODORT Councilor, Publications Committee Chair, and Bylaws and Organization Coordinator. Terms of all elected officers shall be one year, unless otherwise specified in the Bylaws. Term of office shall begin at the start of new business at the second Steering Committee meeting of the Annual Conference. The Treasurer shall take office September 1 and shall serve a two-year term. The Bylaws and Organization Coordinator shall serve a two-year term (with the option of a oneyear term extension, at the discretion of the GODORT Chair and approval of the Steering Committee). The GODORT Councilor's term of office is governed by the ALA Bylaws.

\section{Section 8.}

\section{Bylaws and Organization} Coordinator.

The Coordinator is responsible for maintenance of GODORT's Bylaws and timely updating of the Policies and Procedures Manual (to reflect current practice). It is not the responsibility of this Coordinator to initiate Bylaws amendments or to draft revisions to the PPM, but rather to receive these from GODORT membership, or appropriate GODORT units, and perform any necessary administrative and editorial tasks.

\section{Article VII. EXECUTIVE COMMITTEE}

This committee is composed of the Chair, the Assistant Chair/ChairElect, Secretary, Treasurer, GODORT Councilor, Publications Committee Chair, the Immediate Past Chair, and the Bylaws and Organization Coordinator.

\section{Article IX. POLICIES AND PROCEDURES}

Operating policies and procedures of GODORT and its subunits are contained in the GODORT Policies and Procedures Manual. The PPM will be maintained by the Bylaws and Organization Coordinator in consultation with other GODORT units, and is published on the GODORT website.

\section{Article XI. AMENDMENTS} Section 2.

Proposals for revision may be sent by any member of the Steering Committee to the Bylaws and Organization Coordinator, which will review the proposed revision and report it to the Steering Committee. ...

\section{Section 3.}

Any personal member(s) may propose amendments with twenty-five supporting signatures. In order to obtain the supporting signature a proposed amendment may be published on the GODORT website with an accompanying form which supporters may sign and return to the Bylaws and Organization Coordinator. Upon receipt of a proposal with twenty-five supporting signatures from personal members, the Bylaws Coordinator will review and report on the language and compatibility of the proposal with other provisions in these Bylaws to the GODORT membership. $\ldots$

RATIONALE: The GODORT Bylaws [Article IV] provide for various "Officers," who are elected by the GODORT membership (from among GODORT members nominated by the Nominating Committee). They serve as voting members of both the GODORT Executive Committee and Steering Committee during the entire term of their elective service. 
The GODORT "Bylaws and Organization Coordinator" assumes responsibility for (1) managing the process by which the Bylaws are amended by vote of GODORT membership, (2) revising the text of the Bylaws and the Policies and Procedures Manual, as necessary, and (3) ascertaining whether a PPM change in one chapter necessitates a change in another part of the PPM and notifying the appropriate GODORT unit in these instances.

Modifications to the Bylaws and $P P M$ originate with and are approved by individual GODORT units (or the GODORT membership, as a whole, in the case of the Bylaws). It is the responsibility of the Bylaws and Organization Coordinator to perform certain administrative tasks, in the case of changes to the Bylaws, and to make necessary adjustments to the text of these documents and to oversee their harmony.

The Bylaws and Organization Coordinator may also, in consultation with the GODORT Chair, undertake annual "educational sessions" concerning the Bylaws and the PPM, to better orient new/returning members of the GODORT Steering Committee as to the difference(s) between these two documents and the proper role of the Steering Committee, as outlined in the Bylaws, and the Committee's accurate relationship to the PPM. The Coordinator may also convene, at his/her discretion, any necessary ad hoc Committee to address extensive Bylaws changes, which may arise. 